\title{
The effects induced hyperglycemia on adrenal cortex function in the giant Danio Devario Aequipinnatus embryos
}

\begin{abstract}
Purpose: The purpose of this study was to induce hyperglycemic experiment in Giant $\mathrm{Da}$ nio embryos in relation to effects of hyperglycemia on adrenal cortex function and steroidogenesis.

Methods: The wild specimens of Devario aequipinnatus fishes collected from the Cauvery river at Stanley Reservoir were induced for breeding without the use of any hormones and the matured embryos were obtained. The embryos of Giant Danio were induced for hyperglycemic stress, by immersing them in $0.0 \%, 0.3 \%, 0.6 \%, 0.9 \%, 1.2 \%, 1.5 \%$, and $1.8 \%$ glucose solution, at $24 \mathrm{~h}, 48 \mathrm{~h}$ and $72 \mathrm{~h}$.

Result: The Giant Danio exposed to glucose solution appear to experience acute stress as indicated by the significant elevation in serum glucose and serum cortisol. The ranges of average cortisol level for all embryo samples exposed for $24 \mathrm{~h}, 48 \mathrm{~h}$ and $72 \mathrm{~h}$ in stock aquaria were: $1.2-6.4 \mu \mathrm{g} / \mathrm{dL}, 0.8$ to $7.6 \mu \mathrm{g} / \mathrm{dL}$ and $0.8-9.6 \mu \mathrm{g} / \mathrm{dL}$ respectively.

Conclusion: The results showed positive correlation between the \%glucose solution and the cortisol level, as well as the incubation time and the cortisol level as reported previously in other model systems.
\end{abstract}

Keywords: diabetes mellitus, hyperglycemia, cortisol, giant Danio

Volume 4 Issue 4 - 2017

\author{
Manickam Raja,Anbarasu Jayanthi, \\ Mathiyalagan Kavitha, Pachiappan Perumal \\ Department of Biotechnology, Periyar University, India
}

Correspondence: Pachiappan Perumal, Department of Biotechnology, Periyar University, Periyar Palkalai Nagar, Salem636 0II Tamil Nadu, India, Tel +9l 427234 5766, Ext. 225, Fax +91 427234 5124, Email perumalarticles@gmail.com

Received: December 25, 2016 | Published: July 21, 2017

\section{Introduction}

Cortisol is the principal glucocorticoid secreted by the interrenal tissue (steroidogenic cells) located in the head-kidney of teleost fish. This hormone is released by the activation of the hypothalamuspituitary-interrenal axis (HPI axis). ${ }^{2}$ When an organism is under stress conditions, the hypothalamus releases corticotropin-releasing factor (CRF) toward blood circulation. This polypeptide further stimulates secretion of adrenocorticotrophic hormone (ACTH) from the anterior pituitary gland ${ }^{3}$ which finally activates the release of cortisol by the interrenal tissue. ${ }^{2}$ In recent years the concept of stress induced changes in fish has awakened the interest among scientists. ${ }^{4}$ The response to stress in fish is characterized by the stimulation of the hypothalamus, which results in the activation of the neuroendocrine system and a subsequent cascade of metabolic and physiological changes. ${ }^{5}$ These changes enhance the tolerance of an organism to face an environmental variation or an adverse situation while maintaining a homeostasis status. ${ }^{6,7}$ Extrinsic factors may affect a variety of biochemical functions within the fish organism such as cortisol biosynthesis and release rates. Background environmental color of an organism is reported to have an effect on cortisol secretion. ${ }^{8} \mathrm{~A}$ higher intensity of cortisol response is documented in Pargus pargus acclimated in black tanks when compared with those found in gray and white tanks when fish were exposed to crowding stress. ${ }^{9}$

The level of cortisol in the blood of fish is a robust index of stress ${ }^{10}$ and, because cortisol is directly implicated in many deleterious effects of stress, stress-induced cortisol levels provide a well-defined trait of functional significance upon which selection pressure can be directed. Strain differences in cortisol responsiveness to stressors have been demonstrated in fish ${ }^{11}$ in that the relative magnitude of the plasma cortisol response to stress of individual rainbow trout is a stable trait within a proportion of the population ${ }^{12}$ and pooled gamete crosses of fish selected for low- and high-cortisol response to stress generate progeny which display traits similar to those of the parental groups. ${ }^{13}$ The Giant Danio is a tropical fish belonging to the family Cyprinidae and phylogenetically closely related to Danio rerio ${ }^{14}$ and is one of the big sized forms among Danionins. Giant Danio has been used as a model in retinal cone electrophysiology, ${ }^{15}$ fine structure of retinal epithelium circuitry and cell electrical coupling, ${ }^{16-18}$ trans species polymorphism in $\mathrm{MHC}$ complex, ${ }^{19}$ neurotrophic factor, ${ }^{20}$ body flow dynamics in swimming, ${ }^{21}$ deafferentation and olfactory bulb morphology, ${ }^{22}$ for vision experiment. ${ }^{23}$ More recently, the Giant Danio has been proposed as a model to study skeletal muscle growth, ${ }^{24,25}$ cardiac remodeling and regeneration ${ }^{26}$ visual impairments of retinal layers. $^{27}$

However, the use of human subjects to study markers of the HPA axis and adrenal function is extremely difficult. Obesity, gender, blood pressure, lifestyle, stress, perception of stress, and psychiatric illnesses are all known to affect cortisol secretion and metabolism as well as the increased risk of developing DM. ${ }^{28,29}$ Using an animal model of DM would allow for control or elimination of many if not all of these confounding factors. Teleost fish, including Giant Danio (Devario aequipinnatus), have previously been shown to be glucose intolerant. ${ }^{27}$ The experimental studies on hyperglycemia in relation to adrenal cortex are still needed, using fish as experimental model. Therefore, the present study was on the induced hyperglycemic experiment in Giant Danio embryos in relation to effects of hyperglycemia on adrenal cortex function and steroidogenesis.

\section{Materials and methods}

\section{Collection, domestication and maintenance of fishes}

The wild specimens of Devario aequipinnatus were collected the 
Cauvery river at Stanley Reservoir, (N $11^{\circ} 54^{\prime} 18.3^{\prime \prime}$ E $\left.77^{\circ} 53^{\prime} 15.8^{\prime \prime}\right)$ Salem District, Tamil Nadu, India, during September to March 2016, using drag net (Figure 1). The live fish samples were transported to the Laboratory in aerated bags and were maintained in a 700 L FRB tank with artificial, continuous aeration at a room temperature of 27$30^{\circ} \mathrm{C}$. The collected fishes were stocked in rearing tanks of size $1.5 \mathrm{~m}$ x $0.5 \mathrm{~m} \times 1.5 \mathrm{~m}$ and mature males and females were kept separately with the density of 6-7 in each tank. The rearing tanks were provided with dark substrate (gravel and pebbles) and mild circulating water current with the help of electric motors for their adaptation. After proper acclimatization and maintenance, the domesticated brood stock was selected for the breeding experiments. The glass tank $(1.5 \mathrm{~m}$ $\mathrm{x} 0.5 \mathrm{~m} \times 1.5 \mathrm{~m}$ ) with dark substrate and natural day lighting provided with spawning mops made of green wool.

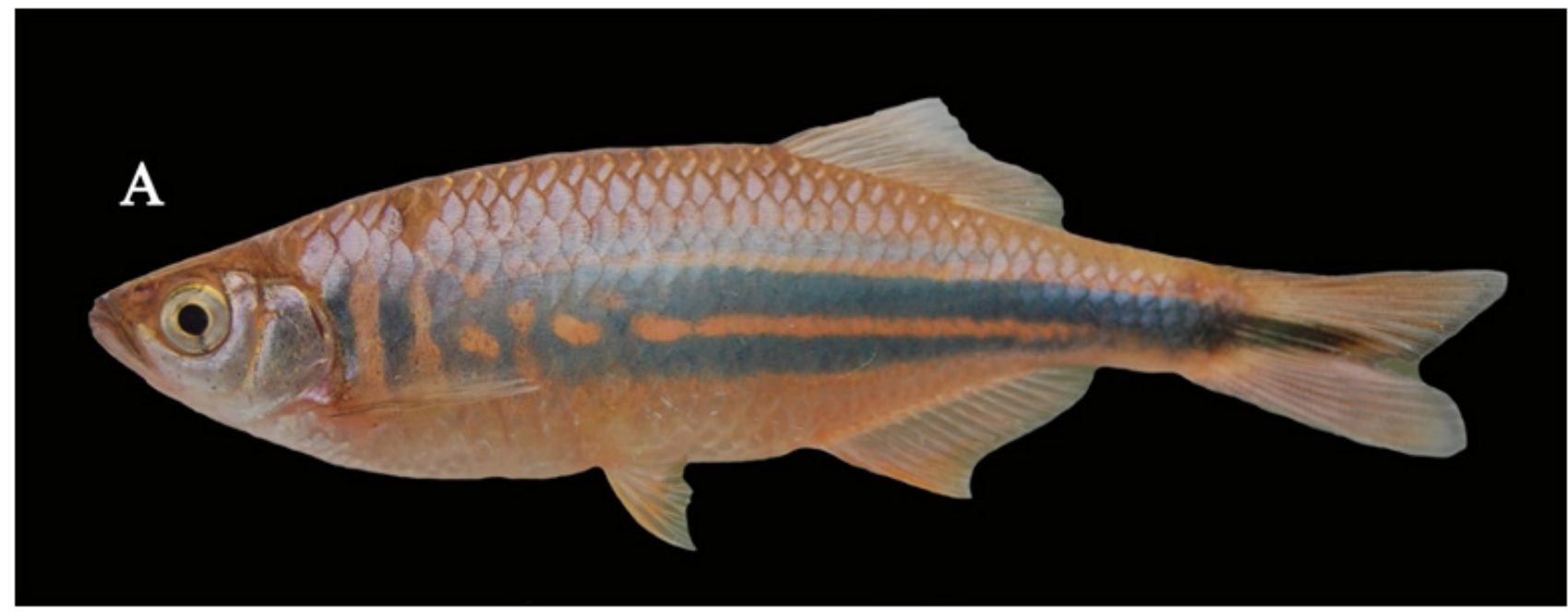

Figure I The Experimental Fish Devario aequipinnatus.

\section{Water quality parameters}

Fresh, dechlorinated and well aerated water was used for domestication of the fish in all the tanks. In the tanks for rearing and breeding experiments, $\mathrm{pH}$ was maintained in the range $6.7 \pm 0.2$, nitrates, nitrites and ammonia were maintained at 0 , hardness in the range of $60-70 \mathrm{mg} / \mathrm{L}$, conductivity in the range of $0.1 \pm 0.02 \mathrm{mg} / \mathrm{S}$, total alkalinity in the range of $30-35 \mathrm{mg} / \mathrm{L}$ and dissolved oxygen in the range of $8.0 \pm 0.5 \mathrm{mg} / \mathrm{L}$. In the rearing tanks temperature of $25 \pm 0.5^{\circ} \mathrm{C}$ was maintained with the help of regulated water heaters. The water temperature was measured with the help of a centigrade thermometer. Alkalinity and total hardness were measured following standard procedures. ${ }^{30}$ Conductivity, $\mathrm{pH}$, and dissolved oxygen were analyzed using meters by Lutron Co. Test kits were used to check nitrates, nitrites and ammonia

\section{Feeding, selection of brood pair, collection of embryos}

The fishes were fed ad libitum with live food (mosquito larvae and chironomous larvae) and with commercially available fish food. The mature females were larger when compared to males and had a rounded belly while the males were slender and streamlined and more colorful. In the spawning tank, one gravid female was released along with two mature males and then their behaviour was observed. If a pair was interested then the male would constantly chase the female all around the tank and hit the female in its abdomen with its head for spawning. If no interest was seen between them then the male was replaced by another mature male to check for the interest between them for spawning. The male which showed interest in the female are kept in the spawning tank and observed till the spawning takes place. After releasing the brood pair in the spawning aquarium, temperature was gradually increased to $27 \pm 0.5^{\circ} \mathrm{C}$ from $25 \pm 0.5^{\circ} \mathrm{C}$ within $48 \mathrm{~h}$. After $48 \mathrm{~h}, 3 / 4$ th of spawning aquarium water was removed and replaced by creating artificial rain with a sprinkler with water $4^{\circ} \mathrm{C}$ cooler than the spawning tank of to $27 \pm 0.5^{\circ} \mathrm{C}$ at night around $10 \mathrm{pm}$. The eggs were removed from the spawning aquarium with a dropper. The embryos were viewed under Magnus stereozoom microscope in 10X magnification and matured eggs were selected for the experiments. Fish maintenance, breeding, embryo collection, and experimental design followed by Dey S et al., ${ }^{31}$ animal care and maintenance protocols approved by the Periyar University Institutional Animal Ethical committee (No. 1085/ac/07/PU/IAEC/2012/10).

\section{Induction of hyperglycemia}

The embryos were allowed to incubate in stock aquaria water at $28^{\circ} \mathrm{C}$ until they naturally hatched from the chorion, or approximately $48 \mathrm{~h}$ post-fertilization (hpf). One hundred and fifty embryos from each clutch were placed in $50 \mathrm{ml}$ of various solutions of glucose $(0.0 \%$, $0.3 \%, 0.6 \%, 0.9 \%, 1.2 \%, 1.5 \%$, and $1.8 \%$ ) prepared using glucose added to stock aquaria water. The embryos were allowed to incubate for 24,48 and $72 \mathrm{~h}$ in the corresponding glucose solutions. Following incubation, the embryos were anesthetized in $0.02 \%$ Tricaine solution. They were then rinsed for $1 \mathrm{~min}$ with stock aquaria water $\times 3$ and placed into a $2 \mathrm{ml}$ micro centrifuge tube. The embryos were briefly centrifuged, all water was removed, hand was homogenized for $30 \mathrm{~s}$, and centrifuged again at $14,000 \mathrm{rpm}$ for $1 \mathrm{~min}$. The glucose level was then obtained by placing $1.5 \mu$ of supernatant to a glucometer strip (One-Touch Select) with three readings taken from each sample.

\section{Cortisol extraction and measurement}

Two hundred microliters of $10 \mathrm{mM}$ Tris- $\mathrm{HCl}$ was added to each sample and then homogenized for 30 s using a rotor-stator homogenizer. The samples were centrifuged at $10,000 \times \mathrm{g}$ for $20 \mathrm{~min}$ at $4^{\circ} \mathrm{C}$. Strata $\mathrm{C} 18$-E columns (Phenomenex, Inc.) were equilibrated according to manufacturer's suggestion. The supernatant from each sample was added to a column and allowed to flow through by gravity. 
The samples were eluted by addition of $500 \mu 1$ of the supplied elution buffer. The samples were placed in a SpeedVac until dry. Cortisol measurements were taken of each sample in triplicate using a Cortisol EIA Kit (Caymen Chemical).

\section{Results}

\section{Induction of hyperglycemia and glucose level in $24 \mathrm{~h}$, 48h and $72 \mathrm{~h}$ embryos}

To induce hyperglycaemia initially, the embryos were treated in a $0.0 \%, 0.3 \%, 0.6 \%, 0.9 \%, 1.2 \%, 1.5 \%$, and $1.8 \%$ glucose solution, as it readily take up substances from the water. ${ }^{32}$ The average glucose measurement for all embryo samples incubated for $24 \mathrm{~h}, 48 \mathrm{~h}, 72 \mathrm{~h}$ in stock aquaria water ranged from 65 to $>600 \mathrm{mg} / \mathrm{dl}$. Glucose concentrations of stock aquaria water were adjusted for samples incubated with glucose such that they remained iso-osmolar. For samples incubated for $24 \mathrm{~h}$ in $0.0 \%, 0.3 \%, 0.6 \%, 0.9 \%, 1.2 \%, 1.5 \%$, and $1.8 \%$ the average glucose measurements level were $82 \pm 1.58 \mathrm{mg} /$ $\mathrm{dl} ; 116 \pm 2.7 \mathrm{mg} / \mathrm{dl} ; 138.8 \pm 3.0 \mathrm{mg} / \mathrm{dl} ; 183.2 \pm 2.4 \mathrm{mg} / \mathrm{dl} ; 225.6 \pm 1.5 \mathrm{mg} / \mathrm{dl}$; $285.4 \pm 4.8 \mathrm{mg} / \mathrm{dl} ; 316.2 \pm 1.3 \mathrm{mg} / \mathrm{dl}$ respectively. For samples incubated for $48 \mathrm{~h}$ in $0.0 \%, 0.3 \%, 0.6 \%, 0.9 \%, 1.2 \%, 1.5 \%$, and $1.8 \%$ the average glucose measurements level were $72.2 \pm 1.7 \mathrm{mg} / \mathrm{dl} ; 145.2 \pm 2.2 \mathrm{mg} / \mathrm{dl}$; $194.4 \pm 1.6 \mathrm{mg} / \mathrm{dl} ; \quad 243.6 \pm 3.8 \mathrm{mg} / \mathrm{dl} ; \quad 316.4 \pm 2.6 \mathrm{mg} / \mathrm{dl} ; \quad 396.4 \pm 1.6 \mathrm{mg} /$ $\mathrm{dl}$ and $445.6 \pm 2.6 \mathrm{mg} / \mathrm{dl}$ respectively. For samples incubated for $72 \mathrm{~h}$ in $0.0 \%, 0.3 \%, 0.6 \%, 0.9 \%, 1.2 \%, 1.5 \%$, and $1.8 \%$ the average glucose measurements level were $67.4 \pm 3.9 \mathrm{mg} / \mathrm{dl} ; 200.4 \pm 3.2 \mathrm{mg} / \mathrm{dl}$; $250.8 \pm 4.1 \mathrm{mg} / \mathrm{dl} ; 324.4 \pm 3.8 \mathrm{mg} / \mathrm{dl} ; 407.6 \pm 2.9 \mathrm{mg} / \mathrm{dl} ; 522.8 \pm 6.2 \mathrm{mg} / \mathrm{dl}$ and $>600 \mathrm{mg} / \mathrm{dl}$ respectively. These results show a direct correlation between the glucose level and induced glucose concentration Figure $2 \mathrm{~A}$.

\section{Blood cortisol levels in $24 \mathrm{~h}, 48 \mathrm{~h}$, and $72 \mathrm{~h}$ induced embryos:}

There was also a significant increase in the cortisol level of hyperglycemia induced embryos. The average cortisol level for all embryo samples exposed for $24 \mathrm{~h}, 48 \mathrm{~h}$ and $72 \mathrm{~h}$ in stock aquaria water ranged from $1.2-6.4 \mu \mathrm{g} / \mathrm{dL}, 0.8$ to $7.6 \mu \mathrm{g} / \mathrm{dL}$ and $0.8-9.6 \mu \mathrm{g} /$ $\mathrm{dL}$ respectively. For samples incubated for $24 \mathrm{~h}$ in $0.0 \%, 0.3 \%$, $0.6 \%, 0.9 \%, 1.2 \%, 1.5 \%$, and $1.8 \%$ the average cortisol levels were: $1.37 \pm 0.17 \mu \mathrm{g} / \mathrm{dL} ; 2.36 \pm 0.18 \mu \mathrm{g} / \mathrm{dL} ; 3.61 \pm 0.25 \mu \mathrm{g} / \mathrm{dL} ; 4.16 \pm 0.05 \mu \mathrm{g} / \mathrm{dL} ;$ $4.97 \pm 0.17 \mu \mathrm{g} / \mathrm{dL} ; 5.76 \pm 0.11 \mu \mathrm{g} / \mathrm{dL}$ and $6.31 \pm 0.08 \mu \mathrm{g} / \mathrm{dL}$ respectively. For samples incubated for $48 \mathrm{~h}$ in $0.0 \%, 0.3 \%, 0.6 \%, 0.9 \%, 1.2 \%, 1.5 \%$, and $1.8 \%$ the average cortisol levels were: $1.0 \pm 0.2 \mu \mathrm{g} / \mathrm{dL} ; 3.1 \pm 0.2 \mu \mathrm{g} /$ $\mathrm{dL} ; \quad 4.2 \pm 0.3 \mu \mathrm{g} / \mathrm{dL} ; \quad 4.7 \pm 0.1 \mu \mathrm{g} / \mathrm{dL} ; \quad 5.9 \pm 0.1 \mu \mathrm{g} / \mathrm{dL} ; \quad 6.6 \pm 0.2 \mu \mathrm{g} / \mathrm{dL}$ and $7.5 \pm 0.1 \mu \mathrm{g} / \mathrm{dL}$ respectively. For samples incubated for $72 \mathrm{~h}$ in $0.0 \%, 0.3 \%, 0.6 \%, 0.9 \%, 1.2 \%, 1.5 \%$, and $1.8 \%$ the average cortisol levels were: $0.84 \pm 0.05 \mu \mathrm{g} / \mathrm{dL} ; 3.54 \pm 0.26 \mu \mathrm{g} / \mathrm{dL} ; \quad 4.77 \pm 0.24 \mu \mathrm{g} / \mathrm{dL}$; $6.06 \pm 0.18 \mu \mathrm{g} / \mathrm{dL} ; 6.91 \pm 0.27 \mu \mathrm{g} / \mathrm{dL} ; 8.09 \pm 0.18 \mu \mathrm{g} / \mathrm{dL}$ and $9.31 \pm 0.30 \mu \mathrm{g} /$ $\mathrm{dL}$ respectively. These results show a direct correlation between the glucose level and cortisol level in hyperglycemia induced embryos.
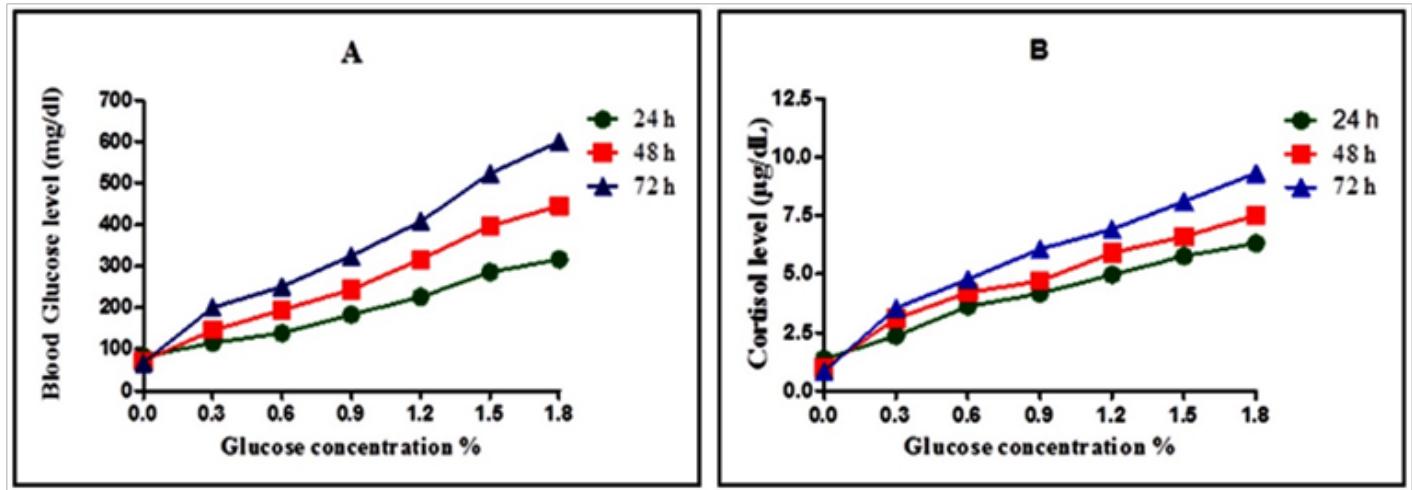

Figure 2

(A) Glucose levels in Giant Danio embryos exposed to $0.0 \%, 0.3 \%, 0.6 \%, 0.9 \%, 1.2 \%, 1.5 \%$, and I.8\% glucose in fish water over a period of 24,48 , and $72 \mathrm{~h}$. Glucose levels for samples incubated for $24 \mathrm{~h}$ ranged from 82 to $316.2 \mathrm{mg} / \mathrm{dl}$; for $48 \mathrm{~h}, 72.2-445.6 \mathrm{mg} / \mathrm{dl}$; for $72 \mathrm{~h}, 67.4$ to 522.8 samples in $1.8 \%$ had glucose levels $>600$.

(B) Cortisol levels in hyperglycemic Giant Danio embryos over a 24,48 and $72 \mathrm{~h}$ period.There is a direct correlation between the \% glucose solution and cortisol levels. There is also a direct correlation between hours in incubation and cortisol level.

\section{Discussion}

The levels of plasma cortisol in Giant Danio Devario aequipinnatus embryos have not previously been reported. The presently obtained data show that levels of cortisol in unstressed Devario aequipinnatus embryos $(0.8-1.2 \mu \mathrm{g} / \mathrm{dL})$ are of a similar order of magnitude to, or higher than, those in other cyprinid species such as the common carp. ${ }^{33-35}$ Following the imposition of hyperglycemia, cortisol levels in Giant Danio embryos were elevated approximately 12 -fold, to a mean level of almost $9.6 \mu \mathrm{g} / \mathrm{dL}$ (the highest individual level recorded in a hyperglycemic embryos during this study was $1.8 \%$ of glucose solution in $72 \mathrm{~h}$ incubation period). The magnitude of this induced hyperglycemia increase, in terms of a proportional elevation above basal levels, is similar to that seen in salmonid fish. However, in absolute terms, the levels of cortisol observed in even nonhyperglycemic embryos far exceed the levels of cortisol known to elicit adverse effects on growth, reproduction, and the immune system in salmonid fish. ${ }^{36,37}$ In fish, cortisol is bound to plasma proteins in considerably lower amounts. ${ }^{38}$ Plasma cortisol levels are known to cycle diurnally and to change according to season. During the day the highest concentration is generally found during morning and then the level declines throughout the day. ${ }^{39}$

There was also a direct correlation between the \%glucose solution and the cortisol level, as well as the incubation time and the cortisol level. These data demonstrate that hyperglycemia can reliably be produced in the Giant Danio Devario aequipinnatus embryos, as has previously shown in Danio rerio species by Gleeson M, ${ }^{32}$ Powers JW 
et al. $^{40}$ The induced hypergylcemia in adult rainbow trout through manipulation of food source and stocking conditions. ${ }^{41}$ Their study showed changes in cortisol levels in conjunction with glucose levels suggesting that hyperglycemia-induced stress results in changes in cortisol levels. Presently, embryonic Giant Danio Devario aequipinnatus from 24 to $72 \mathrm{hpf}$ was used, a period during which the embryos nutritional demands might have been supplied by the yolk sac. ${ }^{42}$ This eliminates any variability in glucose levels being attributed to natural variations in food intake, ${ }^{43}$ using the same Cortisol EIA kit used in our studies, showed a natural increase in production of cortisol starting around the time of hatching, approximately 48hpf. The Present investigation showed data indicate that there is an increased level of cortisol present in embryos associated with hyperglycemia. It remains unclear, however, if hyperglycemia induces a stress-response leading to increased production of cortisol, as could be measured by increased ACTH levels, or if hyperglycemia impairs hydroxysteroiddehydrogenase activity resulting in decreased metabolism of cortisol.

The normal adult size of the Giant Danio ranges between 6 and $10 \mathrm{~cm}$, which is more than four times the average adult size of zebrafish. Also, when compared to the zebrafish, the Giant Danio exhibits $129 \%$ increase in growth following exogenous growth hormone application ${ }^{44}$ Therefore, unlike the zebrafish, the Giant Danio appears to exhibit indeterminate growth, even though it is very closely related to the zebrafish.

Changes in blood cortisol levels in the hyperglycemic embryos are considered to be a more direct indicator of the activity of the hypothalamic-pituitary-interrenal HPI axis than changes in glucose levels following stress. The induced hyperglycemia increase in circulating levels of cortisol is believed to be wholly dependent on de novo biosynthetic activity within the interrenal tissue. This in turn is dependent on stimulation by adrenocorti- cotropin ACTH secreted by the pituitary, following stimulation of the pituitary corticotropes by corticotropin-releasing hormone $\mathrm{CRH}$ of hypothalamic origin. ${ }^{45}$ 'Resting' cortisol levels are low $0.8-1.6 \mu \mathrm{g} / \mathrm{dL}$ in controlled Giant Danio embryos and which can increase more than 10 fold of glucose exposure of the fish to a stressful stimulus. While the untreated fish exhibited a low mean serum cortisol level $(0.8-1.6 \mu \mathrm{g} / \mathrm{dL})$, the stressed fish (glucose treated) showed a high mean serum cortisol level $(9.6 \mu \mathrm{g} /$ $\mathrm{dL}$ ) after $72 \mathrm{~h}$ period of exposure. A significant increase in serum cortisol concentration was seen in the glucose exposed embryos.

An increased blood glucose level has led to hyperglycemia stress that resulted in various clinical conditions and many disorders such as cardiovascular, microvascular diseases, traumatic brain injury, periodontal diseases and also cause increased vulnerability to other diseases. ${ }^{46}$ Diabetes can damage neurons, ${ }^{47}$ Glia fibrillary acidic protein:48,49 and vascular tissues within the retina ${ }^{50}$ such neural alterations includes the presence of apoptosis ${ }^{51,52}$ in the inner retinal layers and photoreceptors in diabetic animals. ${ }^{53}$

The result of the present study show that Giant Danio exposed to glucose solution appear to experience acute stress as indicated by the significant elevation in serum cortisol and serum glucose. Post-stressor increases in blood glucose levels have also been used as monitors; glucose levels are easy to measure and relatively inexpensive, and are the most commonly measured indicator of the secondary phase stress response in fish. ${ }^{11}$ Since this increased result, in part, has been from cortisol-induced gluconeogenesis, blood glucose changes have sometimes been used as indirect measures of altered cortisol secretion. Plasma cortisol levels rise rapidly following acute exposure to physical stressors. ${ }^{56}$ It has been considered that elevated plasma cortisol levels increase the susceptibility of fish to fungal, bacterial, and parasitic infections. ${ }^{5}$ Cortisol has been widely used to assess the state of health of the fish exposed to stress condition. ${ }^{6}$ Changes in the concentration of plasma cortisol, however, depend upon the nature of stress stimuli and the duration of the stress as well as due to the magnitude and severity of stress ${ }^{7}$ and the type of species under investigation. ${ }^{55}$ In the present study, since there is a significant increase in the cortisol concentration immediately after exposure and continuous increase till $72 \mathrm{~h}$, it could be concluded that fishes exposed to the glucose concentration undergo an immediate stress. ${ }^{56}$

The induced hyperglycemia stress increases in plasma glucose levels in several species of fish..$^{57,58}$ The concurrent increase in glucose and cortisol in channel catfish following a $2 \mathrm{~h}$ low-water confinement. ${ }^{58}$ The significant correlation between cortisol and glucose in contrast to a clear absence of correlation for hyperglycemic embryos. Cortisol is usually considered to have a hyperglycemic effect ${ }^{2}$ and, indeed, it has been reported that fish exposed to increased levels of cortisol had shown an increased glucose levels ${ }^{59}$ which could explain the significant correlation described herein. Zebrafish have similar metabolic regulation of glucose as that found in mice and human, ${ }^{60}$ and the Giant Danio is phylogenetically closer to Danio rerio. ${ }^{14}$ Effects of induced hyperglycemia stress resulted in positive correlation between the $\%$ glucose solution and the cortisol level, as well as the incubation time and the cortisol level as seen previously in other model systems, consistent with onset of adrenal cortex function and steroidogenesis. ${ }^{32}$ In conclusion, the present study demonstrated that hyperglycemic effects on adrenal cortex function and steroidogenesis in the freshwater fish Giant Danio Devario aequipinnatus embryos. Hence, it is proposed that the effects of hyperglycemia induced stress, adrenal cortex function and steroidogenesis in Giant Danio could form a reproducible and complementary model and hence the fish can be tried as a new "model" for conducting biomedical experiments.।

\section{Acknowledgements}

None.

\section{Conflict of interest}

Author declares that there is of conflict of interest.

\section{References}

1. Iwama GK, Vijayan MM, Forsyth RB, et al. Heat shock proteins and physiological stress in fish. American Zoologist. 1999;39(6):901-909.

2. Mommsen TP, Vijayan MM, Moon TW. Cortisol in teleosts: dynamics, mechanisms of action, and metabolic regulation. Reviews on Fish Biology and Fisheries. 1999;9(3):211-268.

3. Fryer JN, Lederis $\mathrm{K}$. Control of corticotropin secretion in teleost fishes. AMER. ZOOL. 1986;26:1017-1026.

4. Barreto RE, Volpato GL. Stress responses of the fish Nile tilapia subjected to electroshock and social stressors. Brazilian Braz J Med Biol Res. 2006;39(12):1605-1612.

5. Wedemeyer GA, Barton BA, McLeay DJ. Stress and acclimation. In: Schreck CB, Moyle PB, editors. Methods for Fish Biology. American Fisheries Society, Bethesda, USA; 1990. p. 491-527.

6. Mazeaud MM, Mazeaud F. Adrenergic responses to stress in fish In: Pickering AD, editor. Stress in Fish. London: Academic Press; 1981;49-75.

7. Pickering AD. Introduction: the concept of biological stress. In: Pickering AD, editor. Stress and Fish. London: Academic Press; 1982. 
8. Van der Salm AL, Martínez M, Flik G, et al. Effects of husbandry conditions on the skin colour and stress response of red porgy, Pagrus pagrus. Aquaculture. 2004;241(1-4):371-386.

9. Rotllant J, Balm PH, Perez-Sanchez J, et al. Pituitary and interrenal function in gilthead sea bream (Sparus aurata L., Teleostei) after handling and confinement stress. Gen Comp Endocrinol. 2001;121(3):333-342.

10. Barton BA, Haukenes AH, Parsons BG, et al. Plasma cortisol and chloride stress responses in juvenile walleyes during capture, transport, and stocking procedures. $N$ American Journal of Aquaculture. 2003;65(3):210-219.

11. Pickering AD, Pottinger TG. Stress responses and disease resistance in salmonid fish: effects of chronic elevation of plasma cortisol. Fish Physiol Biochem. 1989;7(1):253-258.

12. Pottinger TG, Moran TA, Cranwell PA. The biliary accumulation of corticosteriods in rainbow trout, Oncorhynchus mykiss, during acute and chronic stress. Fish Physiol Biochem. 1992;10(1):55-66.

13. Pottinger TG, Mosuwe E. The corticosteroidogenic response of brown and rainbow trout alevins and fry to environmental stress during a critical period. Gen Comp Endocrinol. 1994;95(3):350-362.

14. Mayden RL, Tang KL, Conway KW, et al. Phylogenetic relationships of Danio within the order Cypriniformes: a framework for comparative and evolutionary studies of a model species. J Exp Zool B Mol Dev Evol. 2007;308(5):642-654.

15. Wong KY, Adolph AR, Dowling JE. Retinal bipolar cell input mechanisms in Giant Danio. Electroretinographic analysis $J$ Neurophysiol. 2005;93(1):84-93.

16. Braekevelt CR. Fine structure of the retinal epithelium and tapetumlucidum in the Giant Danio (Danio malabaricus) (teleost). Anat Embryol (Berl). 1980;158(3):317-328.

17. McMahon DG, Mattson MP. Horizontal cell electrical coupling in the Giant Danio: synaptic modulation by dopamine and synaptic maintenance by calcium. Brain Res. 1996;718(1-2):89-96.

18. Wagner TL, Beyer EC, McMahon DG. Cloning and functional expression of a novel gap junction channel from the retina of Danio aequipinnatus. Vis Neurosci. 1998;15:1137-1144.

19. Graser R, O'Huigin C, Vincek V, et al. Trans-species polymorphism of class II MHC loci in Danio fishes. Immunogenetics. 1996;44(1):36-48.

20. Adams DS, Kiyokawa M, Getman ME, et al. Genes encoding Giant Danio and golden shiner ependymin. Neurochem Res. 1996;21(3):377-384.

21. Wolfgang MJ, Anderson JM, Grosenbaugh MA, et al. Near-body flow dynamics in swimming fish. J Exp Biol. 1999;202(Pt 17):2303-2327.

22. Poling KR, Brunjes PC. Sensory deafferentation and olfactory bulb morphology in the zebrafish and related species. Brain Res. 2000;856(1-2):135-141

23. Van Roessel P, Palacios AG, Goldsmith TH. Activity of long wavelength cones under scotopic conditions in the cyprinid fish Danio aequipinnatus. J Comp Physiol A. 1997;181(5):493-500.

24. Biga PR, Goetz FW. Zebrafish and Giant Danio as models for muscle growth: determinate vs. indeterminate growth as determined by morphometric analysis. Am J Physiol Regul Integr Comp Physiol. 2006;291(5):R1327-1337.

25. Biga PR, Meyer J. Growth hormone differentially regulates growth and growth-related gene expression in closely related fish species. Comp Biochem Physiol A Mol Integr Physiol. 2009;154(4):465-473.

26. Lafontant PJ, Burns AR, Grivas JA, et al. The Giant Danio (D. aequipinnatus) as a model of cardiac remodeling and regeneration. Anat Rec (Hoboken). 2012;295(2):234-248.
27. Raja M, Kavitha M, Ramkumar R, et al. The 'Giant Danio'(Devario aequipinnatus) - Another Model for Diabetic Retinopathy Study: Induction of Hyperglycemia and Resultant Retinal Impairment. Endocrinol Diabetes Res. 2016;1:2

28. Reynolds RM, Walker BR, Syddall HE, et al. Elevated plasma cortisol in glucose-intolerant men: differences in responses to glucose and habituation to venipuncture. J Clin Endocrinol Metab. 2001;86(3):1149-1153.

29. Andrew R, Phillips DI, Walker BR. Obesity and gender influence cortisol secretion and metabolism in man. J Clin Endocrinol Metab. 1998;83(5):1806-1809.

30. APHA. Standard Methods for the Examination of Water and Waste Water. 20th ed. Public Health Ass. Washington, DC, USA; 1998.

31. Dey S, Ramanujam SN, Mahapatra BK. Breeding and development of ornamental hill stream fish Devario aequipinnatus (McClelland) in captivity. International Journal of Fisheries and Aquatic Studies. 2014;1(4):01-07.

32. Gleeson M, Connaughton V, Arneson LS. Induction of hyperglycemia in zebrafish (Danio rerio) leads to morphological changes in the retina. Acta Diabetol. 2007;44(30):157-163.

33. Dabrowska H, Dabrowski K, Meyer-Burgdorff K, et al. The effect of large doses of vitamin $\mathrm{C}$ and magnesium on stress responses in common carp, Cyprinus carpio. Comp Biochem Physiol A Comp Physiol. 1991;99(4):681-685.

34. Van Dijk PLM, Van den Thillart GEEJM, Wendelaar Bonga SE. Is there a synergistic effect between steady state exercise and water acidification in carp? Journal of Fish Biology. 1993;42(5):673-681.

35. Pottinger TG. Changes in blood cortisol, glucose and lactate in carp retained in anglers' keepnets. Journal of Fish Biology. 1998;53:728-742.

36. Pickering AD, Pottinger TG. stress responses and diseases resistance in salmonid fish: effects of chronic elevation of plasma cortisol. Fish Physiol Biochem. 1989;7(1-6):253-258.

37. Carragher JF, Sumpter JP, Pottinger TG, et al. The deleterious effects of cortisol implantation on reproductive function in two species of trout, Salmo trutta L. and Salmo gairdneri Richardson. Gen Comp Endocrinol. 1989;76(2):310-321.

38. Caldwell CA, Kattesh HG, Strange RJ. Distribution of cortisol among its free and protein-bound fractions in rainbow trout (Oncorhynchus mykiss): evidence of control by sexual maturation. Comp Biochem Physiol A Comp Physiol. 1991;99(4):593-595.

39. Zima T, Kazda A, Pro AR, et al. Laboratory diagnostic. 1st Ed. Praha: Galén; 2002. 728p.

40. Powers JW, Mazilu JK, Lin S, et al. The effects of hyperglycemia on adrenal cortex function and steroidogenesis in the zebrafish. Mol Genet Metab. 2010;101(4):421-422.

41. Conde-Sieira M, Aguilar AJ, Lopez-Patino MA, et al. Stress alters food intake and glucosensing response in hypothalamus, hindbrain, liver, and Brockmann bodies of rainbow trout. Physiol Behav. 2010;101(4):483-493.

42. Westerfield M. The Zebrafish Book: A Guide for the Laboratory Use of Zebrafish (Danio rerio). Eugene: University of Oregon Press; $2007 ; 3.1-3.2$

43. Alsop D, Vijayan M. Development of the corticosteroid stress axis and receptor expression in zebrafish. Am J Physiol Regul Integr Comp Physiol. 2008;294(3):R711-719.

44. Simpson P, Peterson B, Hughes N, et al. Recombinant bovine somatotropin enhances growth rates in two species of ornamental fish; Giant Danios (Danio aequipinnatus) and zebrafish (Danio rerio) (Abstract). J Anim Sci. 2000;78:139. 
45. Sumpter JP. The endocrinology of stress. In: Iwama GK, Pickering AD, Sumpter JP, editors. Fish Stress and Health in Aquaculture. Cambridge: Cambridge University Press; 1997. p. 95-118.

46. Rovlias A, Kotsou S. The influence of hyperglycemia on neurological outcome in patients with severe head injury. Neurosurgery. 2000;46(2):335-342.

47. Barber AJ, Antonetti DA, Gardner TW. Altered expression of retinal occludin and glial fibrillary acidic protein in experimental diabetes. The Penn State Retina Research Group. Invest Ophthalmol Vis Sci. 2000;41(11):3561-3568.

48. Barber AJ, Lieth E, Khin SA, et al. Neural apoptosis in the retina during experimental and human diabetes: early onset and effect of insulin. J Clin Invest. 1998;102(4):783-791.

49. Gaucher D, Chiappore JA, Paques M, et al. Microglial changes occur without neural cell death in diabetic retinopathy. Vision Res. 2007;47(5):612-623.

50. Bursell SE, Clermont AC, Kinsley BT, et al. Retinal blood flow changes in patients with insulin-dependent diabetes mellitus and no diabetic retinopathy. Invest Ophthalmol Vis Sci. 1996;37(5):886-897.

51. Martin PM, Roon P, Van Ells TK, et al. Death of retinal neurons in streptozotocin-induced diabetic mice. Invest Ophthalmol Vis Sci. 2004;45(9):3330-3336.

52. Gastinger MJ, Singh RS, Barber AJ. Loss of cholinergic and dopaminergic amacrine cells in streptozotocin-diabetic rat and Ins2Akita-diabetic mouse retinas. Invest. Ophthalmol Vis Sci. 2006;47(7):3143-3150.
53. Park SH, Park JW, Park SJ, et al. Apoptotic death of photoreceptors in the streptozotocin-induced diabetic rat retina. Diabetologia. 2003;46(9):1260-1268

54. Pickering $\mathrm{AD}$, Pottinger TG, Carragher JF. Differences in the sensitivity of brown trout, Salmo trutta L., and rainbow trout, Salmo gairdneri Richardson, to physiological doses of cortisol. J Fish Biol. 1989;34:757-768.

55. Waring CP, Stagg RM, Poxton MG. Physiological responses to handling in the turbot. Journal of Fish Biology. 1996;48:161-173.

56. Reddy PK, Leatherland JF. Stress Physiology. In: Fish disease and disorders, Vol. 2 Non-infectious Disorders, editors. Leatherland JF, Woo PTK: Cabi Pub; 1998. p. 279-301.

57. Robertson L, Thomas P, Arnold CR, et al. Plasma cortisol and secondary stress responses of red drum to handling, transport, rearing density, and a disease outbreak. Prog Fish-Cult. 1987;49(1):1-12.

58. Davis KB, Griffin BR, Gray WL. Effect of handling stress on susceptibility of channel catfish Ictalurus punctatus to Ichthyophthirius multifiliis and channel catfish virus infection. Aquaculture. 2002;214:55-66.

59. Vijayan MM, Leather land JF. High stocking density affects cortiso secretion and tissue distribution in brook char, Salvelinus fontinalis. $J$ Endocrinol. 1990;124(2):311-318.

60. Jorgens K, Hillebrands JL, Hammes HP, et al. Zebrafish: a model for understanding diabetic complications. Exp Clin Endocrinol Diabetes. 2012;120(4):186-187. 